\title{
EFFECTIVENESS OF MZ200O MYCORRHIZAL BIOFERTILIZER ON THE GROWTH OF SENGON SEEDLINGS
}

\author{
Fahrizal Hazra1)* and Rifqi Puja Novtiar') \\ 1)Department of Soil Science and Land Resources, Faculty of Agriculture, IPB University, Jl. Meranti Campus \\ Darmaga Bogor IPB 16680. \\ 2)Land Resource Management Study Program, Department of Soil Science and Land Resources, Faculty of \\ Agriculture, IPB University, Jl. Meranti Campus Darmaga Bogor IPB 16680.
}

\begin{abstract}
Mycorrhizal biofertilizers contain fungi that are capable of entering and symbiotic mutualism into plant roots and increasing the ability of plants to absorb nutrients. Fertilizer effectiveness testing is needed to protect consumers from the adverse effects of using biofertilizers. This study aims to determine the effectiveness of MZ2000 mycorrhizal biofertilizers and to know mycorrhizal root infections in sengon seedlings in nurseries. The combination treatment of $30 \mathrm{~g}$ MZ2000 mycorrhizal biofertilizer with $5 \mathrm{~g}$ NPK fertilizer gave the best sengon growth results although it was not significantly different in several parameters compared to the combination treatment of MZ2000 fertilizer dosage and other NPK fertilizers, with the value of agronomic relativity (Relative Agronomic Effectiveness / RAE) 580.80\% for high growth and 288.72\% for growth in stem diameter and incremental benefit cost ratio (IBCR) analysis of farming by 2.48 . So that the dosage of the combination treatment of mycorrhizal biofertilizers and NPK fertilizer is most agronomically and economically effective. With the effectiveness of the fertilizer, the MZ2000 mycorrhizal biofertilizer can be declared to have passed the field effectiveness test.
\end{abstract}

Keywords: Effectiveness test, IBCR, relative agronomic effectiveness, sengon.

\section{INTRODUCTION}

Quality and effectiveness tests of biofertilizers are carried out to protect consumers from the adverse effects of the use of biofertilizers. The results of the MZ2000 mycorrhizal biofertilizer quality test conducted by the Department of Soil Science and Land Resources of IPB have met the standard criteria for the Ministry of Agriculture Regulation No. 70 / Permentan / SR.140 / 10/2011 can be seen in Appendix 4. with the number of spores 626 spores / g consisting of Glomus, Acaulospora, and Gigaspora. MZ2000 mycorrhizal biofertilizer must then be tested for effectiveness in plants to determine the response of growth and root infection to plants. The results of this effectiveness test were taken into consideration to issue a biofertilizer distribution permit.

Arbuscular mycorrhizal fungi (endomycoriza) or better known as FMA is a form of symbiotic mutualism between plant roots and fungi. This beneficial form of symbiosis occurs throughout the life of the plant. MZ2000 mycorrhizal biofertilizer that produced by PT. Inagro is a type of endomycorrhizae that is capable of symbiosis with almost $90 \%$ of plant species, from agricultural crops, horticulture, plantation crops, and forestry plants. This effectiveness test research is expected to be able to show the effectiveness of MZ2000 mycorrhizal biofertilizers on the growth of sengon seedlings in nurseries, so that the final results would pass the effectiveness test according to the Ministry of Agriculture regulations. This study aims to determine the effectiveness of MZ2000 mycorrhizal biofertilizer and to determine mycorrhizal root infection and plant growth on sengon seedlings in the nursery.

\section{METHODOLOGY}

This research was conducted for 6 months, from February to July 2019 at Bogor, West Java. Analysis of the root infection was carried out at the Soil Biotechnology
Laboratory and soil analysis was carried out at the Soil Chemical and Fertility Laboratory, Department of Soil Science and Land Resources, Faculty of Agriculture, IPB.

The material used in this study was acid soil from Bogor, sengon seeds, Mikoriza MZ2000 from PT. Inagro, zeolite, NPK fertilizer standard, root coloring agents in the form of alcohol, aquades, $\mathrm{H}_{2} \mathrm{O}_{2}, \mathrm{KOH} 2.5 \%, \mathrm{HCl} 0.1 \mathrm{~N}$, trypan blue $0.02 \%$, glycerin $50 \%$, glucose solution $60 \%$, Melzer solution. The tools used in this study were stereo microscopes, ovens, autoclaves, analytical balance, glass bottles, film bottles, polybags $(20 \times 20) \mathrm{cm}$, watering can, trapping shelves, refrigerators, petri dishes, stratified filters measuring $250 \mu \mathrm{m}, 125 \mu \mathrm{m}$, and $63 \mu \mathrm{m}$, centrifuge, glass beaker, test tube, measuring cup, spatula, pipette, glass preparation, glass cover, scissors, digital camera, label, spoon, tweezers, hoe, and stationery.

The type of plants used to test the effectiveness of MZ2000 biofertilizers is a fast growing forestry plant species, namely sengon. Sengon plants are widely used for reforestation programs and the wood industry. In order to increase the growth of seedlings in the nursery and increase the resilience of the seeds after planting in the field, the nursery stage requires the administration of mycorrhizae.

The experimental design used was a single Completely Randomized Design (CRD) with 6 treatments and 10 replications, so that the total experimental unit was 60 polybags. The treatment of biofertilizer testing were as follows:

$$
\begin{aligned}
& A=\text { Control } \\
& B=\text { standard NPK }(16-16-16) 10 \mathrm{~g} \\
& C=0 \mathrm{NPK}+30 \mathrm{~g} \text { of MZ2000 biofertilizer } \\
& \mathrm{D}=0.25 \mathrm{NPK}+30 \mathrm{~g} \text { of MZ2000 biofertilizer } \\
& \mathrm{E}=0.50 \mathrm{NPK}+30 \mathrm{~g} \text { of MZ2000 biofertilizer } \\
& \mathrm{F}=0.75 \mathrm{NPK}+30 \mathrm{~g} \text { of MZ2000 biofertilizer }
\end{aligned}
$$

(Based on the Minister of Agriculture Regulation No. 70 / Permentan / SR. 140/10/2011). 
According to Wasis and Fathia (2010), application of $10 \mathrm{~g}$ NPK fertilizer had the most significant effect on increasing the height growth of gmelina seedlings by $109.72 \%$ compared to the doses of $0 \mathrm{~g}, 5 \mathrm{~g}$ and $15 \mathrm{~g}$, so that the standard NPK dose made was $10 \mathrm{~g}$.

The seedling media used were zeolites which put in a sprout tub. Sengon seeds were sown in the media and maintained for 2 weeks until they were ready to wean. The planting media used were acid soil from Ciseeng, Bogor. The soil is then sifted and put in a $20 \times 20 \mathrm{~cm}$ polybag.

Mycorrhizal inoculation was carried out in conjunction with sengon seedling weaning. Then make a hole with a depth of $5 \mathrm{~cm}$ on soil media in a polybag, then MZ2000 mycorrhizae inserted in the hole. After that the sengon seedlings were moved into the hole with the root position facing down in contact with mycorrhizae at the base and edge of the planting hole. The hole was closed again with soil and watered. Basic NPK fertilizer (16-1616) is given two days before the sengon seedlings are planted in a poly bag. Giving NPK according to the treatment dose by sprinkling around a polybag $5 \mathrm{~cm}$ away from the seeds.

Height and diameter measurements are carried out every 2 weeks. Sengon seedlings are measured starting from the base of the stem to the tip of the leaf tip. The measurement of shoot and root dry weight was carried out at the end of the observation by cutting the shoots and roots from plant samples. Each part of the plant is put into paper and labeled. After that the sample is dried in an oven at 70 ${ }^{\circ} \mathrm{C}$ for 72 hours until a constant dry weight is achieved. The sample is then weighed using a scale. The total dry weight of seedlings is obtained by adding up the dry weight of the roots and shoots.

The percentage of root colonization is the data used to see the effectiveness of mycorrhizae in infecting roots. Previously, the roots were stained so that they could be easily observed under a microscope. The roots are washed using water until clean, then soaked in a $20 \% \mathrm{KOH}$ solution for 1-3 days until the roots appear white. The roots are washed under running water then immersed in $0.1 \mathrm{M}$ $\mathrm{HCl}$ solution without washing afterwards. The roots are immersed in trypan blue solution for 1-3 days. The roots are washed from the trypan blue solution and finally soaked in a destaining solution made of a mixture of glycerin, lactic acid, and distilled water for 24 hours. The roots are then cut approximately $1 \mathrm{~cm}$ and placed in a row on the glass object. Every 5 pieces of root are covered with a glass cover. Root infection can be seen through the presence of vesicles, arbuscula, and hyphae, which infect the roots. The percentage of root colonization is calculated using the formula (1).

Growth data and crop yields are presented in graphical form or curve and processed statistically with ANOVA followed by comparison between treatments with Duncan test at $5 \%$ test level. The linear design model is as follows (2).

Evaluation of the technical / agronomic effectiveness is carried out by calculating the Relative Agronomic Effectiveness (RAE) with the formula (3).

The economic effectiveness of fertilizer is assessed by calculating Benefit Cost Ratio (B / C), Revenue Cost Ratio (R / C) or Index Benefit Cost Ratio (IBCR), using the formula (4).

$$
\begin{gathered}
\text { Root colonization }(\%)=\frac{\text { Total infected root }(\%)}{\text { Total field of view observed }} \times 100 \% \\
\varepsilon(Y) i j=\mu+T i
\end{gathered}
$$

Information: $\boldsymbol{\varepsilon}(\mathrm{Y}) \mathrm{ij}=$ Random effects of $\mathrm{i}$ treatment and $\mathrm{j}$ test

$\mu=$ General score

$\mathrm{Ti}=$ Random effect of the $\mathrm{i}$ treatment

Information:

$$
R A E=\frac{\text { The results of the tested fertilizes-Control }}{\text { Results of standard fertilizers-Control }} \times 100 \%
$$

- RAE value of standard treatment $=100$

- RAE value $>100 \%$, the fertilizer tested is more effective than standard treatment.

Information:

$$
I B C R=\frac{\text { Estimated amount of fertilizers used-Control }}{\text { Actual amount of fertilizers used-Control }}
$$

IBCR or B / C or R / C > 1 means that the tested fertilizer had good economic value

Provisions Pass Test

- The fertilizer treatment tested statistically was the same as the standard treatment or had a RAE if greater equal to $100 \%$.

- The fertilizer treatment tested was better than the controlled treatment, at a significant leveled of 5\%.

- The used of biofertilizers was assessed to passed the economic effectiveness test if the economic analysis of the farming business was profitable, namely the value of IBCR or B / C or R / C> 1 .

- Percentage of root colonization to saw the effectiveness of mycorrhizae in infected roots. 


\section{RESULTS AND DISCUSSION}

Growth is a quantitative change during the life cycle of plants that is irreversible. According to Davis and Jhonson (1987), upward growth (height) is primary growth, while sideways growth (diameter) is called secondary growth. The parameters used to determine the quality of seedlings are plant height, stalk diameter, shoot dry weight, and root dry weight. While the percentage of root colonization is a parameter to determine the suitability of the host plant with the inoculated MZ2000 mycorrhizal fertilizer. The results in Table 1 explains the interaction between MZ2000 mycorrhizal biofertilizers and NPK fertilizer. Almost all test parameters have a very significant effect except on root dry weight which has only a significant effect. Recapitulation of the growth rate of sengon seedlings can be seen in Table 1.

Table 1. Recapitulation of variability of 12 MST sengon seedlings

\begin{tabular}{|c|c|}
\hline Test Parameters & Variety Findings \\
\hline Plant Height & $* *$ \\
\hline Stalk Diameter & ** \\
\hline Shoot Dry Weight & ** \\
\hline Root Dry Weight & $*$ \\
\hline Root Colonization (\%) & ** \\
\hline $\begin{array}{rll}\text { Note: } & * * & =\text { very significant } \\
& * & =\text { significant effec } \\
& \text { effect on }(\mathrm{P}>0.05\end{array}$ & $\begin{array}{l}01) \text {, } \\
.05) \text { and tn = no sign }\end{array}$ \\
\hline
\end{tabular}

\section{Plant Height, Stalk Diameter, Shoot Dry Weight and Root Dry Weight of Sengon Plants}

Plant height is an indicator of growth that is used to see the growth of sengon plants. According to Wasis et al. (2012), plant height is the simplest growth indicator used to determine environmental influences or the treatment given. Likewise with the diameter of the plant stem which is one indicator in the growth of sengon which is quite often used in addition to plant height. The size of the plant diameter is influenced by soil quality and plant age.

Arbuscular mycorrhizal fungi (AMF) help increase nutrient absorption by associating with plant roots. This can be seen from the value of plant shoot dry weight and root dry weight. The combination treatment between NPK fertilizer and MZ2000 mycorrhizal biofertilizer showed significant results on height, stalk diameter, shoot dry weight, and root dry weight growth compared to other treatments (Table 2). This shows that the combination of MZ2000 and NPK mycorrhizal biofertilizer can meet the nutrient requirements of plants so that it showed better results.

Based on Table 2. the best results for height and diameter growth were obtained in the combination fertilizer treatment, namely 5 g NPK +30 g MZ2000 biofertilizer.
The high growth of MZ2000 mycorrhizal biofertilizer treatment without NPK was not significantly different from the treatment that was given NPK alone, this might be because biofertilizers could not substitute nutrient requirements needed by plants such as nitrogen, phosphate and potassium. Nitrogen in plants functions as a form of amino acids and proteins that are used in stimulating the growth of the vegetative phase of plants (Novizan, 2002). The combination treatment of NPK fertilizer and MZ2000 mycorrhizal biofertilizer showed higher differences in height and diameter compared to other controls and treatments. Mycorrhiza causes the coverage of nutrient uptake in the soil to increase so that nutrient intake from NPK fertilizer can be absorbed more optimally. The optimal absorption of NPK fertilizer increases plant growth.

The best results for shoot dry weight were obtained in combination fertilizer treatment, namely $7.5 \mathrm{~g} \mathrm{NPK}+30$ $\mathrm{g}$ MZ2000 biofertilizer. The treatment was not significantly different from the treatment of $5 \mathrm{~g} \mathrm{NPK}+30 \mathrm{~g}$ of MZ2000 biofertilizer, so it is better to use a dose of $5 \mathrm{~g} \mathrm{NPK}+30 \mathrm{~g}$ of MZ2000 biofertilizer because it is more economical and the results are still very good. While the best results for root dry weight were obtained in combination fertilizer treatment, namely $2.5 \mathrm{~g} \mathrm{NPK}+30 \mathrm{~g}$ MZ2000 biofertilizer. This can be seen in Table 2 seedlings infected by mycorrhizae showed better growth compared to standard NPK fertilizer treatments. This is in accordance with Nusantara et al. (2012) that the symbiosis of AMF and plant roots is said to be effective if it produces a beneficial effect on the host plant. In this study mycorrhizae will associated with the roots of sengon seeds to help increase the nutrient absorption needed by plants.

\section{Root Colonization}

The percentage of root infection comes from infection in each area that is seen under a microscope. The percent yield of root colonization is classified according to criteria according to Rajapakse and Miller (1992) namely, less than 5\% is very low, $6-25 \%$ is low, $26-50 \%$ is moderate, $51-75 \%$ is high, and above $75 \%$ is very high. The ability of each type of arbuscular mycorrhizal fungi (AMF) to infect plant roots is different. According to Garg and Chandel (2010), symbiotic formation of AMF starts from AMF soil propagules, asexual spores, or mycorrhizal roots colonizing with host plants, then form apressoriums around the roots of host plants. The fungus then penetrates into the root cortex and forms internal hyphae and arbuscules. After colonization with the host plant, the mycelium develops outside the roots in search of water and nutrients through external hyphae. The results of root colonization can be seen in Figure 1.

Table 2. Effect of MZ2000 mycorrhizal biofertilizer application with several doses of NPK fertilizer on height, stalk diameter, shoot dry weight and root dry weight of sengon plants.

\begin{tabular}{|c|c|c|c|c|}
\hline Treatment & Plant Height $(\mathrm{cm})$ & Stalk Diameter $(\mathrm{mm})$ & Shoot Dry Weight $(\mathrm{g})$ & Root Dry Weight (g) \\
\hline Control & $19.66^{\mathrm{c}}$ & $2.42^{\mathrm{c}}$ & $2.23^{\mathrm{c}}$ & $1.93^{\mathrm{bc}}$ \\
\hline Standard NPK (16-16-16) $10 \mathrm{~g}$ & $22.16^{\mathrm{bc}}$ & $2.94^{\mathrm{bc}}$ & $3.56^{\mathrm{b}}$ & $1.54^{\mathrm{c}}$ \\
\hline $0 \mathrm{~g} \mathrm{NPK}+30 \mathrm{~g}$ of MZ2000 biofertilizer & $22.22^{\mathrm{bc}}$ & $3.01^{\mathrm{b}}$ & $2.98^{\mathrm{bc}}$ & $1.76^{\mathrm{c}}$ \\
\hline $2.5 \mathrm{~g} \mathrm{NPK}+30 \mathrm{~g}$ of MZ2000 biofertilizer & $28.58^{\mathrm{ab}}$ & $3.67^{\mathrm{a}}$ & $5.11^{\mathrm{a}}$ & $2.94^{\mathrm{a}}$ \\
\hline $5 \mathrm{~g} \mathrm{NPK}+30 \mathrm{~g}$ of MZ2000 biofertilizer & $34.18^{\mathrm{a}}$ & $3.91^{\mathrm{a}}$ & $5.65^{\mathrm{a}}$ & $2.62^{\mathrm{ab}}$ \\
\hline $7.5 \mathrm{~g} \mathrm{NPK}+30 \mathrm{~g}$ of MZ2000 biofertilizer & $33.08^{\mathrm{a}}$ & $3.82^{\mathrm{a}}$ & $5.72^{\mathrm{a}}$ & $2.08^{\mathrm{bc}}$ \\
\hline
\end{tabular}

Note: Numbers followed by the same letter in the same column are not significantly different at the level = 5\% with the Duncan Multiple Range Test 


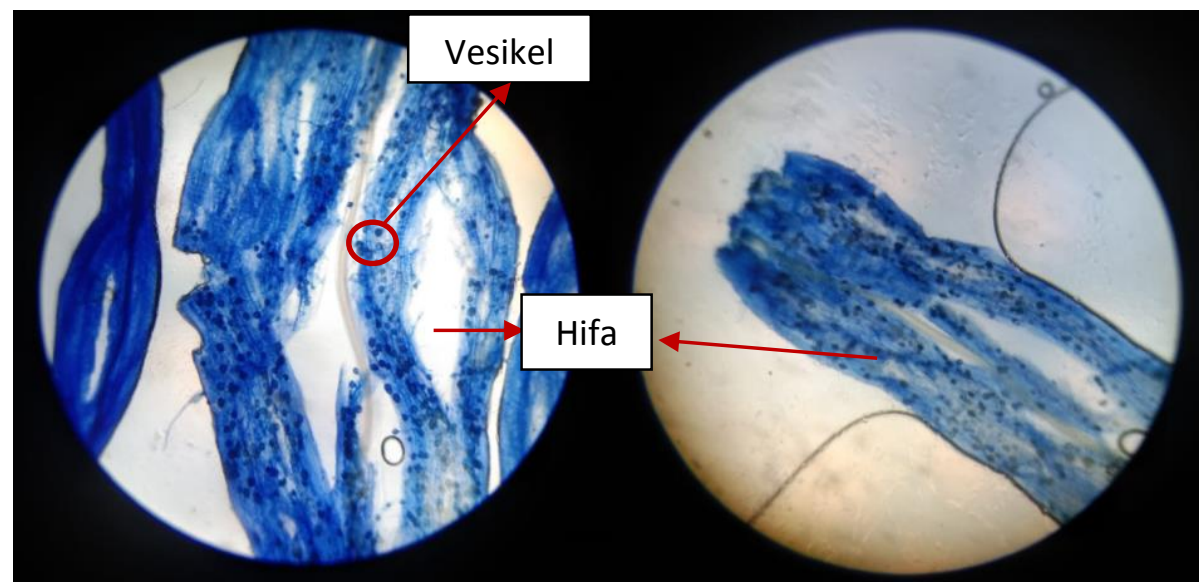

Figure 1. Sengon roots infected by mycorrhiza seen from a microscope

Results of Duncan's Multiple Range Test of root colonization in the control treatment, standard 16-16-16 NPK fertilizer, $30 \mathrm{~g}$ MZ2000 mycorrhizal fertilizer, $30 \mathrm{~g}$ MZ2000 mycorrhizal fertilizer with $2.5 \mathrm{~g}$ NPK fertilizer, 30 g MZ2000 mycorrhizal fertilizer $30 \mathrm{~g}$ with $5 \mathrm{~g}$ NPK fertilizer, and $30 \mathrm{~g}$ MZ2000 mycorrhizal fertilizer with 7.5 g NPK fertilizer are $2.00^{\mathrm{b}}, 6.00^{\mathrm{b}}, 76.00^{\mathrm{a}}, 74.00^{\mathrm{a}}, 74.00^{\mathrm{a}}$, $66.00^{\mathrm{a}}$. This shows that the results of all treatments using MZ2000 mycorrhizal biofertilizer are not significantly different from one another but were significantly different when compared to the control treatment and standard NPK fertilizer treatment alone. So that all treatments that use MZ2000 mycorrhizal biofertilizer successfully infect roots. This is because the percentage of FMA ability to infect roots is classified as high, which is $51-75 \%$ according to what was stated by Rajapakse and Miller (1992). The percentage of root colonization is influenced by the type of AMF, $\mathrm{pH}$, temperature, humidity, heavy metals, and nutrient content (Wood, 1995).

\section{Relative Agronomic Effectiveness (RAE)}

Relative Agronomic Effectiveness (RAE) is an assessment of technical / agronomic effectiveness. The effectiveness of biofertilizers is calculated using the RAE value, which is a comparison between the effect of the tested fertilizer with the effect of fertilizer that is commonly used. In this case as a comparison is the standard N, P, K treatment that has been set to have $100 \%$ effectiveness. The RAE value is calculated based on the ratio of the difference in yield from fertilizer treatments tested with standard NPK multiplied by $100 \%$. RAE calculation results can be seen in Table 3.

Based on the calculations in Table 3 the highest RAE value was obtained in the treatment of $5 \mathrm{~g} \mathrm{NPK}+30$ $\mathrm{g}$ of biofertilizer MZ2000, namely $580.80 \%$ for height growth and $288.72 \%$ for diameter growth so that the RAE results in the treatment were better than the RAE fertilizer N, P, K standard (100\%).

\section{Farm Business Analysis}

Analysis of the farming business must assess the effectiveness of fertilizer economically, which is done by calculating the incremental benefit cost ratio (IBCR). The overall IBCR ratio > 1 means it is quite profitable. The results of the sengon farming analysis are presented in Table 4.

Table 3. RAE values of the effectiveness of MZ2000 mycorrhizal biofertilizers on sengon

\begin{tabular}{lcc} 
& Treatment & RAE Value \\
& Diameter & - \\
\hline Control & 100 & - \\
Standard NPK (16-16-16) 10 g & 113.62 & 100 \\
0 g NPK + 30 g of MZ2000 biofertilizer & 102.40 & 356.80 \\
2.5 g NPK + 30 g of MZ2000 biofertilizer & 580.80 \\
5 g NPK + 30 g of MZ2000 biofertilizer & 243.19 & 536.80 \\
7.5 g NPK + 30 g of MZ2000 biofertilizer & 288.72 \\
\hline
\end{tabular}

Table 4. Analysis of farming in testing the effectiveness of MZ2000 biofertilizers per 60 seedlings

\begin{tabular}{lccc}
\hline \multicolumn{1}{c}{ Treatment } & Input Cost & Selling Price \\
(Rp.) & IBCR & - \\
\hline Control & 60,240 & 90,000 & 90,000 \\
Standard NPK (16-16-16) 10 g & 78,240 & 90,000 & 1.65 \\
0 g NPK + 30 g of MZ2000 biofertilizer & 63,240 & 90,000 & 3.97 \\
2.5 g NPK + 30 g of MZ2000 biofertilizer & 67,740 & 90,000 & 2.48 \\
5 g NPK + 30 g of MZ2000 biofertilizer & 72,240 & 90,000 & 1.80 \\
7.5 g NPK + 30 g of MZ2000 biofertilizer & 76,740 & 9 \\
\hline
\end{tabular}

Note: IBCR: incremental benefit cost ratio; Seed price of Rp. 100,000 / kg, NPK (16-16-16) Rp. 30,000 / kg, MZ2000 Rp. 50,000, - / kg, seedlings Rp. 1,500/ seed 
According to Ismunadji (1989) that the economics calculation of fertilizer use depends on three factors, namely: 1) increase in yield per unit of fertilizer input, 2) price per unit of fertilizer, 3) price obtained per unit of yield. Economically, among the fertilizer treatments tested, the most favorable treatment is $0 \mathrm{~g}$ NPK $+30 \mathrm{~g} \mathrm{MZ2000}$ biofertilizer with an IBCR value of 9.92 .

\section{CONCLUSION}

Mycorrhizal biofertilizers can reduced the need for NPK fertilizer by up to $50 \%$. The combination treatment 30 $\mathrm{g}$ of MZ2000 biofertilizer with $5 \mathrm{~g}$ NPK fertilizer gave the best sengon growth results, although it was not significantly different in some parameters with the combined treatment dose of MZ2000 fertilizer and other NPK fertilizers. The combination treatment of $30 \mathrm{~g}$ MZ2000 mycorrhizal biofertilizers with $5 \mathrm{~g}$ NPK fertilizers is most agronomically and economically effective.

\section{ACKNOWLEDGMENTS}

The author thank PT. INAGRO for their support and trusts in conducting an effectiveness test at the Faculty of Agriculture, IPB University.

\section{REFERENCES}

Davis, L.S. and K.N. Jhonson. 1987. Forest Management. Mc Graw-Hill Book Company, New York.
Garg, N. and S. Chandel. 2010. Arbuscular mycorrhizal networks: proses and function A review. Agron Sustain Dev., 30:581-599.

Ismunadji. 1989. Kalium : Kebutuhan dan Penggunaannya Dalam Pertanian Modern. Balai Penelitian Tanaman Pangan Bogor, Bogor.

Novizan. 2002. Petunjuk Pemupukan yang Efektif. Agromedia Pustaka, Jakarta. Hal 23-24.

Nusantara, A.P., Y.H. Bertham and I. Mansur. 2012. Bekerja dengan Fungi Mikoriza Arbuskula. Kerjasama SEAMEO BIOTROP dengan IPB press, Bogor.

Rajapakse, S. and Jr. J.C. Miller. 1992. Methods for studying vesicular-arbuscular mycorrhizal root colonization and related root physical properties. Methods Microbiol, 24:302-316.

Wasis, B. and N. Fathia. 2010. Pengaruh pupuk NPK dan kompos terhadap pertumbuhan semai gmelina (Gmelina arborea Roxb.) pada media tanam bekas tambang emas (tailing). Jurnal Ilmu Pertanian Indonesia, 16 (2): 123-129.

Wasis, B., B.H. Saharjo, H.S. Arifin and A.N.N. Prasetyo. 2012. Land covers change and its impact to carbon stocks in Ciliwung Watershed. Jurnal Silvikultur Tropika, 3(2): 108-113.

Wood, M. 1995. Enviromental Soil Biology2nd. Chapman \& Hall, Cambridge. 